\title{
The Toy Industry Is Declining? How Can Mattel, Inc. Survive?
}

\author{
Debora J. Gilliard \\ Metropolitan State University - Denver \\ David Lynn Hoffman \\ Metropolitan State University - Denver \\ Sally Baalbaki \\ Metropolitan State University - Denver
}

Will the iconic Barbie doll survive? Mattel, Inc. 's sales are declining, the company has lost its Disney Princess line to Hasbro, and the industry is changing. Today's kids outgrow toys at a younger age and are drawn to video games and electronics. The competitive market is changing as more companies are entering international markets. Mattel's CEO has a challenge to turnaround the downward spiral of revenues.

\section{INTRODUCTION}

"We just didn't sell enough Barbie dolls" stated Mattel CEO Bryan Stockton in February 2014, when he reported a 13\% drop in fourth quarter 2013 sales (O'Connor, 2014). Forbes noted that Barbie sales were still in a slump with a 3\% decline in sales for fourth quarter 2015 that included a $14 \%$ decline in overseas sales. The dismal decline continued with first quarter 2017 worldwide net sales and gross sales down 15\% (Mattel press release 4/20/17).

New CEO Margo Georgiadis, who was hired as Mattel's new CEO in January 2017, has her work cut out for her. Although the company had strong holiday sales at the end of 2016, the momentum did not carry over to the first quarter of 2017. The company saw major declines in sales of its core toys such as Barbie, American Girl, and the Construction and Arts \& Crafts unit. In addition, major competitor, Hasbro, who recently took over the Disney Princess line from Mattel, is on a roll with stock prices up and revenues rising (La Monica, 2017).

Is Mattel selling the toys that kids want today? Are tablets, video games, and technology-related toys overtaking traditional toys? Is the issue at Mattel or the result of a changing industry? What does Mattel and Georgiadis need to do to turn the company around?

\section{THE MATTEL STORY}

The founders of Mattel, Inc. grew up in Denver, Colorado. Ruth Mosko grew up in the prosperous east side of town and attended East High School. Isador Elliot Handler, "Izzy", belonged to a friendly 
gang called the Gigolos (a mix of Jewish and Italian kids from the west side of town) and attended North High School. They saw each other about town, but first met in 1932 at a 'Nickel a Dance' party held at the B'nai B'rith building. After graduating from high school, Ruth went on vacation to Los Angeles and got a job at Paramount Studios in the stenographic pool. A month later, Izzy followed Ruth to Los Angeles and enrolled in the Art Center School of Design - he had a dream of becoming a cartoonist. To pay for school and living expenses, he took a job making lighting fixtures. After they married in 1938, Elliot became fascinated with creating new designs out of new materials, especially a new plastic called lucite. They found a place to use as a workshop and Elliot made lamps, picture frames, hand mirrors, and candelabra and Ruth set about making sales calls to sell the items. Elliot continued experimenting with new designs and began making jewelry pieces. The jewelry was a hit and was worn by many Hollywood starlets. After issues with business partners, the Handler's left the company, began focusing on making wood frames with flocking and in 1945 Ruth and Elliot Handler along with friend and business partner Harold "Matt" Matson launched a new company called Mattel. The first products Mattel sold were picture frames, and then they expanded to doll furniture and eventually added toys to the product line. When Mattel incorporated in 1948 the main product was toys. Company highlights through the years include the following (Mattel website, 2017; Wikipedia, 2017):

- 1955: Advertised toys through the Mickey Mouse Club TV show

- 1959: Barbie was introduced - named after the Handler's daughter, Barbara

- 1960: Mattel IPO

- 1961: Mattel introduces the Ken doll, named after the Handler's son

- 1968: Hot Wheels cars introduced

- 1968: Acquired Monogram Models, the first of many acquisitions

- 1975: Elliot and Ruth Handler leave the company

- 1977: Intellivision home video electronic games were introduced. All non-toy subsidiaries were sold

- 1988: A new alliance with Disney allowed Mattel to produce toys, games, and puzzles based on classic Disney characters such as Mickey Mouse, Winnie the Pooh, and the Disney Princesses

- 1993: Mattel merged with Fisher-Price

- 1997: Mattel merged with Tyco Toys

- 1997: Adopted Global Manufacturing Principles and commits to responsible manufacturing practices.

- 1998: Acquired Pleasant Company and the American Girl brand

- 2000: Mattel became the Harry Potter Toy licensee

- 2001: Barbie's first movie debuted

- 2003: American Girl Place opened on Fifth Avenue.

- 2007: Recalled 18 million products with issues with lead surface coverings and magnets that could detach from toys

- 2012: Merger with HIT Entertainment who owned Thomas and Friends toys

- 2013: Fortune named Mattel one of the top 100 companies to work for

- 2014: Acquired Mega Brands

- 2016: Lost the license to Disney Princess lines to Hasbro Toys

- 2016: Acquired Fuhu - maker of Nabi tablets

- 2016: NBC Universal announced Mattel received the license to make toys based on Jurassic Park franchise 


\section{COMPANY OPERATIONS}

"Mattel is more than a toy company. We seek to make a meaningful difference in the lives of children around the world through play. One of the ways we do this is by creating toys that inspire and empower young minds to imagine beyond boundaries and shape a better world" (Mattel Citizenship, 2017). Mattel, Inc. designs, manufactures and markets a broad range of toy products. It sells 8,000 unique products in 150 countries and has operations in 40 countries. The company has about 32,000 employees.

The company's mission "is to be the recognized leader in play, learning and development worldwide" (10-K 2016 FYE). CEO Margaret Georgiadis identified five strategic priorities for the coming years:

- Build powerful brand franchises

- Establish Toy Box as the partner of choice

- Develop unmatched commercial excellence

- Drive continuous cost improvements

- Build emerging market leadership

\section{Business Brand Categories and Business Segments (10-K FYE 2016)}

Mattel has identified four categories for their major brands: 1) Mattel Girls and Boys Brands which include Barbie, Polly Pocket, DC Super Hero Girls, Hot Wheels, Matchbox, CARS, DC Comics, WWE Wrestling and Toy Story. 2) Fisher-Price Brands including Fisher-Price toys, Little People, Thomas \& Friends, Dora the Explorer, Mickey Mouse Club House, and Power Wheels. 3) American Girl Brands which include the American Girl dolls and related products. 4) Construction and Arts \& Crafts Brands that include MEGA BLOKS and RoseArt.

The company has also identified two geographic segments and the American Girl segment for operating purposes and each are separately managed business units. The North American segment sells products from all brand segments. During the 2017 year the Barbie brand will continue with its "You Can Be Anything" campaign by highlighting various role models. Technology and connectivity will continue to be added to new Barbie products. Hot wheels will be adding new track sets, cars, and a new digital gaming experience. Toy Box will continue to partner with entertainment companies such as Disney, Warner Bros., Entertainment, Inc., Nickelodeon, NBCUniversal Media, and WWE to develop new products. Fisher Price will introduce the next phase of the Best Possible Start Campaign in 2017 (the core message is parental love and play is the best start for child development) and products will have a new contemporary design to attract millennial parents. The International segment will sell generally the same products that are sold in the North American segment with a few adaptations for the international market as needed. The International segment accounts for $40 \%$ of gross sales. The American Girl segment introduced Gabriela McBride in January 2017 as the new Girl of the Year. New characters will be introduced throughout 2017 and the first American Girl boy doll was launched in February 2017 (10-K, FYE 2016).

\section{Manufacturing}

Mattel toys are manufactured in company-owned facilities, third-party manufacturers and some are purchased directly from vendors who design, develop and manufacture their own products. Most core products are made in company-owned facilities in order to maintain flexibility in making products and to reduce costs. Manufacturing plants are located in Canada, China, Indonesia, Malaysia, Mexico, and Thailand. Using facilities in multiple countries allows the company to minimize manufacturing disruptions that may occur due to political or economic instability and changes in government policies. The company uses historical data, market research results, and market information when setting production schedules. Orders and cancellations are affected by changing buying patterns of customers, consumer acceptance of products, competition, and retail marketing strategies. In the toy industry, orders may be changed or cancelled any time prior to shipment (10-K, FYE 2016). 


\section{Product Design and Development}

Mattel uses a group of professional designers and engineers to refresh, redesign, and develop new toys. Independent designers who bring products to Mattel are typically paid a royalty of the net selling price for the products licensed to Mattel. Mattel spent \$215.3 million on product development in 2016 (10-K, FYE 2016).

\section{Marketing and Sales}

Mattel employs multiple advertising venues to promote its products, especially during the holiday season. Advertising is done through television, radio, magazine, newspaper, internet, and social media. Promotions include in-store displays, sweepstakes, major events, and tie-ins with consumer product companies.

Toys and other products are sold directly to retailers which include toy stores, discount stores, chain stores, and department stores and directly to consumers through its websites. In 2016, its 3 largest customers were Wal-Mart, Toys "R" Us and Target which accounted for $39 \%$ of net worldwide sales and its ten largest customers accounted for about $49 \%$ of net sales. Mattel operates some retail outlets that are located near its headquarters or distribution centers. In the international segment, the company sells not only to retailers and wholesalers but also uses agents and distributors in countries where Mattel has no physical presence. The American Girl products are sold directly to consumers, selected retailers, and through its 20 American Girl Retail stores located throughout the United States (10-K, FYE 2016).

The 2016 MIPTV spring market was held in Cannes, France and is a global marketplace for digital content with both producers and buyers attending. At this event Mattel received the "Brand of the Year" honor and announced the formation of a new content division called Mattel Creations. New content introduced at MIPTV included Mattel's 60-minute special titled "Fireman Sam: Alien Alert"; new international characters that will appear in the "Thomas \& Friends: The Great Race" movie; and a re-boot of the "Bob the Builder" series to be shown in new international markets (License! Global, May 2016).

Social media has become an ever-important promotional channel in the world of marketing. Brands that don't have a social media presence nowadays are behind, and probably not doing very well in their industry. Brands use different social media platforms for different reasons, and a social media strategy is usually put in place to help a company build and maintain a social media presence online (Tuten \& Soloman, 2014).

Mattel's social media presence is vast. As a parent company, they have a presence on Facebook, twitter, Instagram and YouTube. However, their individual brands can be found on many other platforms including, but not limited to, Pinterest, LinkedIn and Instagram. The main Mattel page lists all the Facebook pages of its brands, the twitter pages of its brands, and the YouTube channels of its brands. Then by clicking on all the different brand specific websites, you can find the direct links to their social media platforms. For example, Barbie's website has links to Instagram, Facebook, twitter, and YouTube.

Some examples of Mattel's use of social media include the following. In 2013, LinkedIn announced "showcase pages" or pages that are dedicated that allow companies to highlight different aspects of their business and build relationships with the right community (Nicholson, 2014). Barbie's showcase page on LinkedIn has over 8,800 followers (none of whom are 12-year-old girls). It has earned nods as one of the most innovative LinkedIn showcase pages created to date. Since times are changing, and moms who control family finances in the average household aren't perusing toy store catalogs, more companies like Mattel have caught on to the way of thinking of Mom 2.0 - giving her daughter a more aspirational role model. In doing so, Mattel is tapping into audiences in a whole new way, connecting professional moms to Barbie as a person, not product. Mattel's marketing team is not selling toys, they are selling a role model (Nicholson, 2014).

The Barbie brand has historically relied on tradition media (TV) and direct-to-consumer messaging such as emails and mailers to promote its brand (Rodriguez, 2015). In 2015, Mattel spent more on the Barbie brand and used a mix of TV, digital, social and direct-to-consumer elements. This came after having been dethroned from the top of the girls' category by Disney's Frozen, so Barbie fights to reclaim its spot. They did this by rolling out the new Barbie Fashionistas line to make Barbie more culturally 
diverse and reflective of the world we live in. In their marketing campaign, they refreshed their approach to TV while exploring digital and social marketing to build the doll's role in pop culture. Mattel swapped out Barbie's straight-forward, feature-focused TV spots with energizing ads that have a robust soundtrack. They did this in order to disrupt the norm of what girls were watching (since TV is still the best way to reach girls). Mattel also created an online lookbook that showcases the full Fashionistas line. The Barbie website also features a new game called My Style Book where kids can create their own fashions for Barbie. The brand also worked with YouTube influencers to talk to girls in a new way and spread the Barbie brand further. In addition, the doll has 815,000 Instagram fans (where the doll is featured doing yoga, cruising the beach, and going out on the town with coffee and shades). The Barbie brand continues to explore new avenues in 2016 and 2017, this was only the beginning for Barbie (Rodriguez, 2015).

Mattel clearly has a strong social media presence, whether we are focusing on the parent company, or all the brands within their portfolio. They know when to use different platforms to communicate with customers and are doing a great job at winning on social media.

\section{Licensing Agreements}

Mattel has entered into a number of licensing agreements with entertainment companies and in 2016 incurred royalty expenses of $\$ 228.9$ million. The company has licensing agreements with: 1) Disney Enterprises for Disney characters such as Mikey Mouse, Jake and the Never Land Pirates, Disney Plans, CARS, and characters from Star Wars and Toy Story. The license agreement for Disney Princess characters expired at the end of 2016 and was not renewed. Disney awarded this license agreement to Hasbro. 2) NBCUniversal that includes the Fast \& Furious and Jurassic World franchises. 3) Viacom International that includes Nickelodeon properties of Dora the Explorer, Blaze and the Monster Machines, and SpongeBob SquarePants. 4) Warner Bros.' Batman, Superman, Wonder Woman, Justice League, and DC Super hero Girls. 5) Microsoft's Halo. 6) Mojang's Minecraft. 7) WWE Wrestling (10-K, 2016 FYE).

\section{Finances}

TABLE 1

INCOME STATEMENT (IN MILLIONS)

\begin{tabular}{|l|c|c|}
\hline & FYE December 31, & FYE December 31, \\
& $\mathbf{2 0 1 6}$ & $\mathbf{2 0 1 7}$ \\
\hline Net Sales & $\$ 5,456.7$ & $\$ 4,882.0$ \\
\hline Gross profit & $\$ 2,554.4$ & $\$ 1,820.8$ \\
\hline Operating Income/Loss & $\$ 519.2$ & $\$(342.8)$ \\
\hline $\begin{array}{l}\text { Income before income } \\
\text { taxes }\end{array}$ & $\$ 409.7$ & $\$(505.0)$ \\
\hline
\end{tabular}

(Source, 10-K, FYE 2017) 
TABLE 2

GROSS SALES BY BRAND (IN MILLIONS)

\begin{tabular}{|c|c|c|}
\hline & $\begin{array}{c}\text { FYE December 31, } \\
2016\end{array}$ & $\begin{array}{c}\text { FYE December 31, } \\
2017\end{array}$ \\
\hline \multicolumn{3}{|l|}{$\begin{array}{l}\text { MATTEL GIRLS \& } \\
\text { BOYS BRANDS }\end{array}$} \\
\hline Barbie & 482.7 & 504.0 \\
\hline Other Girls & $\$ \quad 242.1$ & 196.2 \\
\hline Wheels & 439.1 & 465.4 \\
\hline Entertainment & 378.7 & 488.2 \\
\hline \multicolumn{3}{|l|}{$\begin{array}{l}\text { FISHER-PRICE } \\
\text { BRANDS }\end{array}$} \\
\hline Core Fisher-Price & 521.9 & 512.3 \\
\hline Fisher-Price Friends & 246.7 & 230.6 \\
\hline Other Fisher-Price & 7.6 & 5.5 \\
\hline $\begin{array}{l}\text { AMERICAN GIRL } \\
\text { BRANDS }\end{array}$ & 2.5 & .1 \\
\hline $\begin{array}{l}\text { CONSTRUCTION } \\
\text { AND ARTS \& } \\
\text { CRAFTS }\end{array}$ & $\$ \quad 124.0$ & \$ 101.3 \\
\hline OTHER & $\$ \quad 2.3$ & $\$$ \\
\hline $\begin{array}{l}\text { TOTAL GROSS } \\
\text { SALES }\end{array}$ & $\$ 2,447.6$ & $\$ 2,503.5$ \\
\hline
\end{tabular}

(Source: 10-K, FYE 2017)

For the fiscal year ending December 31, 2017, net sales were down 11\%, gross sales were down $9 \%$ in constant currency with an operating loss of $\$ 342.8$ million. Net sales in the North American region were down 17\%. Barbie sales had single digit growth (Mattel press release, 2-1-18). In the past five years, Mattel's stock price hit a high of $\$ 47.58$ on December 1, 2013 and a low of $\$ 12.96$ on April 16, 2018. (Yahoo Finance, May 2018).

\section{THE TOY INDUSTRY}

As reported in IBIS World (DeCarlo, 2017), Mattel, Inc. is in the Toy \& Craft Supplies Wholesaling Industry in the U.S. Between the years 2012-17 this industry had a growth rate of $-2.4 \%$ and it is expected to have a growth rate of $-1.1 \%$ between 2017 and 2022. Total annual revenue is about $\$ 25.1$ billion. MarketLine (December 2016) reports that the toys and games market will see compound annual growth of $6.3 \%$ between 2015 and 2020 .

There are a number of factors that impact this industry. When consumer confidence is high, consumers will more freely purchase nonessential items. It is predicted that the consumer confidence index will fall in 2017 (DeCarlo, 2017). When involved in international business, currency fluctuations can greatly impact revenues. Inflationary economies may result in currency devaluation which negatively impact company profits. Companies may mitigate currency fluctuations like Mattel does - by using local currency to acquire inventory and/or enter into forward exchange contracts (10-K, $2016 \mathrm{FYE})$.

Consumers are changing their buying habits and delaying holiday purchases until just before the holiday (10-K, FYE 2016). Beginning in the early 2000s with the advent of software and technology being incorporated into games, manufacturers noticed that children between the ages of 8 and 12 (the major users of traditional toy products) began to outgrow toys at a younger age and began demanding cellphones, tablets and computers and by 2005 there was a growing youth electronics market. This shift 
has increased demand in the video game market. In 2017, traditional toy sales account for $49.1 \%$ of the industry revenue and video game sales account for $24.3 \%$ of the industry revenue. Miscellaneous toys such as fireworks and coloring books account for $10.2 \%$ of revenue and other arts and crafts items make up the remainder of revenues (DeCarlo, 2017).

Retail stores are more often by-passing wholesalers and going directly to manufacturers, such as Mattel and Hasbro, to purchase toys. This is positive for companies like Mattel that are vertically integrated. Large buyers, such as Wal-Mart \& Target, are gaining bargaining power in the industry and demanding lower prices (DeCarlo, 2017).

The competitive environment has become more intense due to shorter life cycles for toy products, increasing use of technology in toys, and children outgrowing toys more quickly. A smaller number of retailers are accounting for a larger portion of toy sales and this gives retailers more power in allocating shelf space, promoting in-store purchases through coupons and specials, and promoting private-label toys. On-line distributors such as Amazon.com can promote a variety of toys and companies with little overhead and low costs (10-K, FYE 2016).

To be successful in the industry, toy companies must have quality products, play value, known brands, and reasonable prices. In the US market, Mattel competes with Hasbro, Jakks, Pacific, Just Play Products, Lego, MGA Entertainment, Moose Toys, Spin Master, VTech, and other smaller companies in addition to the companies that manufacture video games and consumer electronics. In the international market, Mattel competes with Famosa, Giochi Preziosi, Hasbro, Lego, MGA Entertainment, Playmobil, Ravensburger, Simba, Spin Master, VTech and many other regional toy companies and manufacturers (10-K, FYE 2016).

Toy products are subject to a number of Government regulations. In the U.S., the Consumer Product Safety Improvement Act of 2008 and the Federal Hazardous Substances Act influence toy manufacturers. Depending on the toy, a company may also be subject to regulations of the Flammable Fabrics Acts or the Food, Drug, and Cosmetics Act. The Consumer Products Safety Commission may require companies to recall, replace, or repair products they have deemed may pose a risk to consumers. Countries around the world have similar product safety regulations that toy companies must comply with. Advertising and promotions are subject to rules set forth by the Federal Trade Commission Act, The Children's Television Act of 1990, and the Federal Communications Commission. Environmental laws may regulate manufacturing process, waste disposal, etc. (10-K, FYE 2016). Intellectual property is difficult to protect, and the counterfeit market has been growing. The Intellectual Property Rights (IPR) Seizure Statistics by Customs and Border Protection (CBP) office of International Trade reports that the number of IPR seizures in the US was 28,865 in 2015. China accounts for $52 \%$ of all IPR seizures in the United States. To protect intellectual property, many companies invest in anti-counterfeiting systems and counterfeitproof the product packaging which increases product costs (MarketLine, December 2016).

\section{MATTEL IN 2018}

Mattel has joined with $\mathrm{ABC}$ and Hudson Media to develop a Shark Tank-like reality show "The Toy Box". In this series, inventors present their toy concepts to a group of mentors. Once the mentors have approved the toy concept, the inventors present their idea on "The Toy Box" to a panel of young judges that includes Sophia Grace Brownlee ("The Ellen Degeneres Show"), Aalyrah Caldwell ("Uncle Buck"), Toby Grey ("The Unexpected John Cena Pran") and Noah Ritter ("The Ellen Degeneres Show") who decide which ideas move to the finals. The judges selected the Artsplash toy which gives kids tools to create 3D art with water by dipping the Aquapen into various colored dyes and placing the colored water onto Artsheets. The Artsheet may be wiped clean and re-used. Mattel has manufactured the toy and it is available exclusively at Toys "R" Us. Richard Dickson, President and COO of Mattel states "The Toy Box has given us a new way to connect with talented inventors and celebrate the creativity and innovation it takes to make a toy" (Mattel press release, May 19, 2017). Of the hundreds of inventors who applied, only 35 made the cut (Lynch, 2017). 
On April 22, 2018, Mattel Inc. announced that CEO Margo Georgiadis is stepping down after serving one year as CEO. Ynon Kreiz, a Mattel Director since June 2017 was named CEO. Kreiz has 20 years of experience in the media and entertainment industry and has served as CEO of Maker Studies Inc. and CEO of Endomol Group (Mattel press release, April 22, 2018).

Where does Mattel go from here? The toy industry is changing, competition is fierce, consumer buying habits are changing, and children are outgrowing toys at a younger age. How will Mattel maintain its viability in the future? New CEO Ynon Kreiz has a challenge to turn the company around and see an increase in revenues.

\section{TEACHING NOTE}

The Mattel Company was founded in 1945 and went public in 1960. It designs, manufactures, and markets a variety of toy products in 150 countries with $40 \%$ of its revenues generated by the international segment. Major brand categories include Mattel Girls \& Boys Brands (Barbie, DC Super Hero Girls, Hot Wheels, Cars, etc.), Fisher-Price Brands (Little People, BabyGear, Laugh \& Learn, Thomas \& Friends, Dora the Explorer, etc.), American Girl Brands, and Construction and Arts \& Crafts Brands (MEGA BLOKS and RoseArt). Mattel has manufacturing facilities located in six countries at company-owned and third-party facilities. It sells products through retailers, company-owned retail stores, online and via agents and distributors. Wal-Mart, Toys "R" Us, and Target are its three largest customers and account for 39\% of worldwide sales. It has licensing agreements with major entertainment companies (Disney, NBCUniversal Media, Warner Bros., Viacom, etc.) to produce toys related to film and television properties. In the past four years, Mattel has experienced declining revenues, although the company continues to add new products, conducts advertising campaigns, and is expanding its content creation with videos and films.

Major trends affecting the industry include increasing competition, changes in consumer buying habits, and children outgrowing toys at an earlier age and becoming more interested in consumer electronics and toys that incorporate technology, such as video games.

Ynon Kreiz the current CEO, began his job in April 2018. How can he turn this company around?

\section{Suggestions for Using the Case}

This case will work well in a management class when discussing concepts such as environmental analysis, company analysis, turnaround strategies, and declining markets. It is appropriate for marketing classes when discussing topics such as brand reputation, marketing techniques, use of social media, and website content.

\section{Learning Objectives}

1. Evaluate Mattel's use of social media.

2. Evaluate Mattel's website.

3. Analyze the macro environment.

4. Analyze the competitive environment using Porter's Five Forces model.

5. Analyze the internal environment of Mattel using a SWOT analysis and a Value Chain Analysis.

6. Make recommendations for future courses of action.

\section{Suggested Assignment Questions}

1. Complete an analysis of Mattel's use of social media. How effectively does the company use social media? What changes would you recommend?

2. Complete an analysis of Mattel's website. How easy is it to navigate? What changes would you recommend?

3. Analyze the macro environmental forces (economic, political/legal, social trends, global, demographics, \& technology). How do the forces impact Mattel?

4. Complete a SWOT analysis. 
5. Complete a Porter's Five Forces analysis

6. Do a Value Chain Analysis of Mattel.

7. Identify Mattel's corporate level strategy. Identify any synergies that may exist.

8. What recommendations would you make to turn the company around?

\section{Answer to Question 1. Complete an Analysis ff Mattel's Use of Social Media. How Effectively Does the Company Use Social Media? What Changes Would You Recommend?}

Social media has become an ever-important promotional channel in the world of marketing. Brands that don't have a social media presence nowadays are behind, and probably not doing very well in their industry. Brands use different social media platforms for different reasons, and a social media strategy is usually put in place to help a company build and maintain a social media presence online.

Mattel's social media presence is vast. As a parent company, they have a presence on Facebook, twitter, Instagram and YouTube. However, their individual brands can be found on many other platforms including, but not limited to, Pinterest, LinkedIn and Instagram. The main Mattel page lists all the Facebook pages of its brands, the twitter pages of its brands, and the YouTube channels of its brands. Then by clicking on all the different brand specific websites, you can find the direct links to their social media platforms. For example, Barbie's website has links to Instagram, Facebook, twitter, and YouTube.

\section{There Are Different Ways to Analyze the Social Activities ff A Company. Here Are Some Useful Steps to Follow:}

\#1: Analyze Facebook Pages

How many followers do they have? What are they posting about? Are their posts mostly internal news, blog posts and articles or mostly external news, or a mix of both? What's their brand voice? How often do they post? How many likes/comments/shares (engagement) do they get per post? Do they run any polls, contests or fun games with their brand?

\section{\#2: Look at Twitter Accounts}

How many followers do they have? How many accounts are they following? (An account with 50,000 followers that is following 500 users probably has more influence than an account with 50,000 followers that's following 49,000 users, unless they bought followers). What do they tweet about? Are they mostly mirroring their Facebook content, or is their content unique to the channel? Are their posts mostly internal, external, or a mix of both? How many favorites/replies/retweets do they average per post? Does one engagement stand out over the others? Have they created lists? What hashtags do they use? Do they run any Twitter chats? Do they use Twitter cards for lead generation, email signups, etc?

How many followers do they have? How many accounts are they following? Are their posts mostly internal, external or a mix of both? How on-brand are their photos? Do they show the product or service in each shot, or do they follow a more lifestyle-oriented content strategy? What hashtags do they use? Do they tag other accounts (such as employees or partner companies) in many of their photos?

\section{\#4: Review YouTube Channels}

What's their video content like, and how on-brand is it? Do they stick to product tutorials or do they branch out to product non-specific tutorials? Do they show company parties and happy hours? How many subscribers do they have? How's their video engagement (number of comments, tone of comments, number of likes and dislikes per video)? What are the related videos on their watch pages? This should give you a good idea of how the YouTube algorithm categorizes their video metadata.

\section{\#5: Evaluate Pinterest Accounts}

How many followers do they have and how many users do they follow? How do they show off their product or service in pins? How do they organize their pins? What are their board names? Are their pins all brand-generated (product pins) or do they re-pin others? 


\section{\#6: Monitor Snapchat, Periscope, and Meerkat Accounts}

Due to the nature of their content, it's difficult to evaluate these channels in one go. But if a company uses them, follow their accounts and check out their content when it goes live. Since most of the content has a 24-hour time limit, you should stay updated in real time. Check what content they are posting? How many interactions do they garner from their fans?

\section{Analysis of Mattel's Use of Social Media}

With respect to Mattel as a parent company, their Facebook page has about 280,000 likes and followers. They share a mix of both internal and external news as well as photo and video content. They post every couple of days at least, and they get a lot of engagement in terms of likes, comments, and shares on their posts. They don't really create contests or run any polls, but they do create event links to let customers know about events for all of their brands.

Mattel joined twitter in September 2009 and has around 3150 followers. They tweet about once or twice a month, and the content is about reminding consumers about deals, coupons, free shipping, or new introductions around their brands. However, the engagement level on their twitter page is very low. They do have some retweets, but other than that consumers aren't really engaging with them. Mattel is mainly using their twitter page as a way to get information or "news" out to its customers that are on twitter.

Mattel's Instagram channel has about 64,000 followers where they post videos and pictures highlighting all their brands (individually). They are definitely on-brand with all their content. They always use the \#Mattel hashtag as well as their other brands' hashtags. They also sometimes include lifestyle hashtags based on what is going on in the environment that they are highlighting. They do tag companies depending on what they are showcasing (ex: @thetoybox, and@ABCnetwork).

As for YouTube, Mattel has about 23,000 subscribers to their channel. Their videos showcase different ways to play with toys, behind the scenes design and use of toys, tours, giveways, commercials, etc. They have a lot of engagement in terms of views on their video content, and consumers seem to be happy with the channel. They also link their individual brand channels to their Mattel company channel so consumers can easily navigate to the brand they wish to follow.

Mattel clearly has a strong social media presence, whether we are focusing on the parent company, or all the brands within their portfolio. They know when to use different platforms to communicate with customers and are doing a great job at winning on social media.

\section{Answer to Question 2. Complete an Analysis of Mattel's Website. How Easy Is It to Navigate? What Changes Would You Recommend?}

Mattel's website is strong and easy to navigate, even for kids! When you go to the website the first thing you see is pictures of all the brands they own. You can then click on each one to go to that specific website. Therefore, they have allowed the Mattel website to be a hub for all the brands, and they then direct you to the specific brand website for more information.

Mattel's website is catering to kids in the sense that you can play games and watch videos right off their site. There is also an apps button that takes you to all the different apps you can download on your devices from Mattel. These are divided by smart phone and tablet apps.

There is also a "shop now" button at the top of the page. This link takes you to another site shop.mattel.com where you can navigate the Mattel shop and purchase any type of toy by filtering by new, brand, category, age, gifts, clearance, and the Mattel Vault. You also have the option of becoming a Very Important Parent "VIP" and saving 20\% while accumulating rewards. An important thing to point out is that all their sites have a "want to hear from Mattel, sign up here" place where you can sign up to receive more information about their brands. This form of permission marketing is very effective in getting data on consumers who are interested in your brand(s).

Mattel also has a "My Mattel" page where you can connect with other people who share your interests. You can explore the dynamic toy and fan community websites on Mattel's site.

In terms of social media, it is difficult to find the platforms they are active on, on their page. You have to go to http://play.mattel.com/social-media to get more information. One of the changes 
recommended is to make their social media icons available on all pages of their website somewhere (so consumers can directly click and follow them on social media).

In general, Mattel and its brands are doing a great job when it comes to their websites, making them easy for consumers to navigate and purchase from.

\section{Answer to Question 3: Analyze the Macro Environmental Forces (Economic, Political/Legal, Social Trends, Global, Demographics, \& Technology). How Do the Forces Impact Mattel? \\ General: Technological - High Influence on Mattel}

There is a shift in children's toys to electronic devices. This part of the industry is gaining in sales and revenue. This environmental factor will increasingly affect the industry and Mattel.

\section{General: Environmental - Moderate Influence on Mattel but Will Increase}

As more customers become aware of environmental issues more consumers will demand environmentally friendly production. Many manufacturers are utilizing manufacturing processes that minimize waste, carbon emissions, and use renewable energy for their plants.

\section{General: Sociocultural}

This factor will have increasing significance for Mattel. Their target market, young children, are moving to electronic toys at much earlier ages. This age will continue to trend downward.

\section{General: Economics - High Influence on Mattel}

All of Mattel's products are dependent on economic conditions which increase or decrease discretionary spending. Another significant worldwide recession would damage Mattel.

General: Legal and Political -High Influence on Mattel.

This industry is heavily regulated, and these regulations will probably increase.

General: International - High Influence on Mattel

A large portion of Mattel's sales and profits are overseas and especially in China. There is increasing competition from foreign toy companies and video/electronic game companies

Many of the environmental factors have high influence on Mattel and many can change rapidly. An industry that is affected by several factors with high influence and factors that change rapidly is considered an unstable and unpredictable market with high uncertainty (Daft and Marcic, 2017).

\section{Answer to Question 4. Complete A SWOT Analysis of Mattel.}

Strengths

Mattel's strengths start with its vision of inspiring and empowering young minds and to be a leader in learning and development. Mattel's company owned manufacturing plants spread around the world protect it from political and other disruptions to its supply lines. It has a broad range of products, 8,000, in over 50 countries with operations in 40 countries. It also uses a broad range of marketing especially during the holiday season encompassing TV, radio, magazine, newspaper, internet and social media. Mattel has a long history in the toy industry and a well-known brand name. The company has made some strategic acquisitions to enhance its product line. Mattel's positive message to young girls that You Can Be Anything is encouraging but could be expanded. This is also true of their Toy Box use of young consumers to develop products.

\section{Weaknesses}

Mattel's revenue and income declines are problematic. While sales of some products increased such as Barbie and Fisher products, other products decreased. While overseas sales increased, American sales decreased by $2 \%$. Mattel is slowly realizing the growth of electronic devices and may miss a major change in the market. 


\section{Threats}

The biggest threat to the whole industry is the decreasing life cycle of toys, the declining age at which Mattel's biggest customer group, young children, outgrow toys and move to electronic devices. All of Mattel's products are dependent on economic conditions driving discretionary spending. During recessions most consumers decrease spending to focus on necessary items. A severe recession could seriously damage Mattel's financials. The industry as a whole is projected to have a negative growth rate out to 2020. The industry is also susceptible to currency fluctuations which Mattel somewhat ameliorates with purchases in local currencies. The industry will experience a decreasing number of potential retail outlets buying their products. In addition, the buyers of their produces, these retail outlets, will have price pressures from the giants such as Wal-Mart and Target who create deep discounts.

\section{Opportunities}

The trend of retailers bypassing companies and going directly to the manufacturers. Increased interest by young people in video games. Increasing number of online distributors. Becoming easier to move into foreign markets with fewer trade restrictions.

\section{Answer to Question Five. Complete A Porter's Five Forces Analysis of Mattel. Suppliers}

Suppliers have little bargaining power over Mattel who maintains their own manufacturing plants around the world. They can also cancel orders up to the shipment date as demand fluctuates.

Buyers

Customers include stores such as toy, discount, department and online purchasers and the ultimate consumer. Because there are many toy and video game choices for customers and the fact that this is a discretionary purchase gives the end user more power.

\section{Possibility of New Entrants}

Even though the industry is mature with big competitors it can also be driven by fads and affected by new entrants especially located in low cost manufacturing countries with internet access. New video game companies may enter the toy market. Although there is a great deal of brand recognition in the industry and a few large players, so this makes entering the market more difficulty.

\section{Competitive Rivalry}

The industry's major players create intense competitive rivalry. All of them watch each other and can easily imitate major moves. It is difficult even for a major player to create and sustain a competitive advantage because others can easily imitate what they are doing.

\section{Substitute Products}

There are many fun activities outside of the toy industry that may be considered substitutes for toys. These activities may include amusement parks, sports, books/reading, etc. Many of these activities are comparably priced to toys, easy to attain, and meet the need to entertain young children. Substitute products have high power.

\section{Conclusions and Implications from the SWOT and Porter's Five Forces Analyses}

The industry is very mature with well-established companies competing against each other. The industry's growth rate is very low out to 2020. The end users are delaying purchases until just before Christmas and the target market is slowly decreasing as they move to electronic toys at earlier ages.

Given these forces it is difficult for any competitor to establish a long term sustainable competitive advantage. Therefore, Mattel will have to continually experiment with new products and product designs. It must continually review the sales of each product and be willing to change or discontinue declining products. A new market that should be explored is introducing electronic elements into new or existing 
toys. Mattel must use its strengths carefully and be aware of the threats in its environment. Survival will be difficult for all the companies in this industry including Mattel.

\section{Answer to Question 6. Do A Value Chain Analysis of Mattel Looking at All Company Activities?}

A value chain analysis examines the internal activities that a company uses to move a product from its suppliers to the end users. Each activity in the chain adds value and costs to the product. If the value exceeds the cost, then that step adds value. The analysis also allows the user to determine the firm's core competencies (Rothaermel, 2017). The primary activities in order are: inbound logistics, operations, outbound logistics, marketing and sales, and service. The activities that support the primary ones include: general administration, human resource management, technology development and procurement (Dess, Lumpkin, Eisner, and McNamara, 2014).

\section{Primary Activities}

Students should be able to have a thorough discussion of each activity to determine if it adds more value than costs and creates a core competency. For example, because Mattel has suppliers from all over the world it is difficult for inbound logistics to achieve the level of a core competency without superior supply chain processes. While Mattel's supply chain may be good, it does not achieve the level of a Wal Mart supply chain. Possible contra arguments are that they control their suppliers and work closely with them.

Astute students could make a case that operations is a core competency because they utilize related diversification, control their suppliers, and have integrated manufacturing that enables them to achieve cost efficiencies that comes with vertical integration. Even more astute students could counter argue that manufacturing cost efficiencies may not help in the market place if consumers are not price conscious within a few dollars - unless costs are excessive. A bigger issue is that as children outgrow toys faster the life cycle of a toy decreases creating the need for flexible manufacturing, faster development time, and decreased cycle time from a concept to a marketable product. Can Mattel adapt to utilize lean and flexible manufacturing processes?

An argument could be made that previously marketing was a core competency based on their past successes. For example, they successfully created brand images for their Barbie and Fisher lines. They utilize a vast range of marketing techniques as mentioned above including TV, radio, holiday advertising, the internet, and social media. They also utilize excellent retail outlets that compete well with competitors. Conversely, IBIS predicts a decreasing number of retail outlets who have difficulty competing with deep discounters like Wal Mart and Target (IBIS, 2017).

They have picked up an a great psychological/demographic marketing niche by advertising to young girls that You Can Be Anything. However, other companies such as Hasbro are currently doing better than Mattel in the market place as Mattel's sales are slipping. The ultimate question for marketing is will it continue to be successful as their main brands, Barbie and Fisher, are decreasing, and young children outgrow toys much faster?

Of the secondary or support activities, human resources and technology are possible core competencies. Mattel hires excellent personnel and spends a lot of money to train and develop them.

Mattel's R\&D is impressive because they spend a lot of money and resources watching the market place, use focus groups, try new products, and quickly incorporate new concepts into their products. However, their competitors also invest heavily in R\&D, so students could argue that it is still a core competency or used to be a core competency that is losing its success.

\section{Answer to Question 7: Identify Mattel's Corporate Level Strategy. Identify Any Synergies That May Exist.}

Mattel is using a differentiation business level strategy. Companies using the first attempt to differentiate their products by emphasizing service, quality, or value. Companies using the latter pursue these strategies but focus on specific target markets. Students could argue either but since Mattel's target 
market is children a better argument could be made that it focuses on this target segment with quality name brand products.

Mattel is implementing a Related Diversification corporate level strategy. There are significant manufacturing, distribution, and marketing synergies for Mattel's products as experience anywhere in the value chain with one product can be used to decrease costs or increase value for other products. Mattel's vertical integration reduces "transaction costs" that occur in non-vertically integrated companies as the products move from supplier to middle person to manufacturers to middle companies to wholesalers to retailers. Each such move creates additional costs which Mattel's structure avoids (Dess, McNamara, \& Eisner, 2014).

\section{Answers to Questions 8: What Recommendations Would You Make To Turn The Company Around?}

Turnaround strategies involve the following steps: critically analyze the company's industry, their strengths, weaknesses, opportunities and threats and then divest the unprofitable products and focus on the current and especially future profitable products. This teaching note has provided the macro environmental analysis, the SWOTS and Porter's Five Forces. The conclusion is that this is a very competitive and mature industry.

Recommendation one: Divest the unprofitable products that are losing money and will probably lose money in the future. Recommendation two: Put additional resources into the most profitable products and especially the overseas market including China and the emerging countries. Recommendation three: Reduce their vertical integration by divesting some of the inefficient plants. Recommendation four: Invest into toys that have electronic technology but also meet their mission statement of encouraging learning and development. In necessary consider strategic alliances to pursue these products 


\section{REFERENCES}

Daft, R.L., \& Marcic, D. (2017). Understanding Management 10 edition. Boston, MA: Cengage Learning.

DeCarlo, J. (2017, March). IBISWorld Industry Report for Toy \& Craft Supplies Wholesaling in the US. Dess, G.C., McNamara, G., \& Eisner, A.B. (2014). Strategic Management: Text and Cases $8^{\text {th }}$ edition. New York, N.Y.: McGraw Hill.

Gensler, L. (2016, April). Amid Barbie Slump, Mattel Tries to Steer The Discussion Elsewhere. Forbes. IBIS World. (2017).

License! Global. (2016). Mattel Shines at MIPTV. Retrieved from www.licensemag.com

Lynch, J. (2017). Mattel teams with ABC to find its next big toy. Adweek, 58(9).

Mattel. (2017). Wikipedia. Retrieved from https://en.wikipedia.org/wiki/Mattel

Mattel, Inc. website (2017).

Mattel, Inc. 10-K Annual Report for Fiscal Year End December 31, 2016.

Mattel, Inc. 10-K Annual Report for Fiscal Year End December 31, 2017.

Mattel, Inc. (2017). Mattel Reports Full Year and Fourth Quarter 2016 Financial Results and Declares Quarterly Dividend. Press Release.

Mattel, Inc. (2017). Mattel Reports First Quarter 2017 Financial Results and Declares Quarterly Dividend. Press Release.

Mattel, Inc. (2017). The 3D Liquid Art set Will Be Manufactured by Mattel and is Now Available Exclusively at Toys " $R$ " Us. Press Release.

Mattel, Inc. (2018). Mattel Reports Full Year and Fourth Quarter 2017 Financial Results and Declares Quarterly Dividend. Press Release.

Mattel, Inc. (2018). Mattel CEO to step down. Press Release,

MarketLine. (2016). Company Profile: Mattel, Inc.

Nicholson, J. (2014). Social Strategy Spotlight: Mattel's LinkedIn Win - Showcasing Barbie in a New Light. BrandNetworks. Retrieved from https://www.ampower.me/article/Social-MediaMarketing/Social-Strategy-Spotlight-Mattels-LinkedIn-Win-Showcasing-Barbie-in-a-New-Light6-149101.

O’Connor, C. (2014). Mattel's Latest Affront To Little Girls: Entrepreneur Barbie. Forbes.

Rodriguez, A. (2015). Barbie Revamps Marketing Following Diverse Product Makeover: New FashionFocused Effort Encourages Self Expression. AdAge. Retrieved from $\mathrm{http}$ //adage.com/article/cmo-strategy/barbie-revamps-marketing-diverse-productmakeover/299062/.

Rothaermel, F. T. (2017). Strategic Management $3^{\text {rd }}$ edition. New York, N.Y.: McGraw Hill. Tuten, T., \& Solomon, M. (2014). Social Media Marketing. Prentice Hall: New Jersey. (2 ${ }^{\text {nd }}$ edition) Yahoo! Finance (2018). Mattel Inc. Financial Analysis and Stock Price. 